\title{
Quo Vadis, Bioeconomy? the Necessity of Normative Considerations in the Transition
}

\section{Sophie Urmetzer ${ }^{1} \mathbb{D} \cdot$ Michael P. Schlaile $^{2,3} \cdot$ Vincent Blok $^{4} \cdot$ Andreas Pyka $^{3}$}

Accepted: 6 December 2021 / Published online: 16 December 2021

(c) The Author(s) 2021

\begin{abstract}
This collection of papers builds on the idea that the bioeconomy provides a framework for potentially effective solutions addressing the grand global challenges by a turn towards an increased use of biological resources, towards renewability and circularity. Consequently, it cannot be perceived as an end in itself. Thus, innovative endeavors within this bioeconomy framework require a serious examination of their normative premises and implications. From different perspectives, the five contributions to the collection demonstrate that for a bioeconomy that is to contribute to the transformation towards sustainability, inquiries into norms, values, and paradigms of innovators and other stakeholders are indispensable. Originating in the spirit of an interdisciplinary workshop on the "The Normative Dimension of Transformations towards a Sustainable Bioeconomy", the collection at hand provides an attempt to facilitate an increased commitment of social sciences into bioeconomy discourses. We learn: the bioeconomy is on the rise as it is, but whether it will guide us the way towards an equitable, environmentally sound, and future-proof economy, heavily depends on the normative guardrails imposed by science, society, and business.
\end{abstract}

Keywords Bioeconomy $\cdot$ Normative $\cdot$ Sustainability transformation $\cdot$ Innovation · System

Recent discussions have shown that the pressing problems and complex challenges humanity is currently facing cannot be adequately tackled by approaches that

Sophie Urmetzer

sophie.urmetzer@uni-hohenheim.de

1 Bioeconomy Office, University of Hohenheim, Stuttgart, Germany

2 Institut Für Ökonomie, Cusanus Hochschule Für Gesellschaftsgestaltung, Coblenz, Germany

3 Institute of Economics, Department of Innovation Economics, University of Hohenheim, Stuttgart, Germany

4 Department of Social Sciences, Wageningen University, Philosophy Group, Wageningen, The Netherlands 
neglect or oversimplify the normative dimension of sustainability transformations (Blok, 2022; Schlaile et al., 2017). To this day, the almost blind trust in innovation has often been based on the assumption that innovation is driven by some kind of natural force that renders inquiries into values and ethics unnecessary or even obstructive (see also Blok, 2020 on a related note). Over centuries, economic growth has become the central normative measure for progress, as it had proven to be the only economic outcome that guaranteed increased overall welfare for humankind. To this day, criteria such as competitiveness, economic performance, and technological leadership remain the underlying guideposts for the formulation and implementation of innovation policies around the world (Bryden \& Gezelius, 2017). The permanently growing body of scientific evidence regarding planetary boundaries and the violations of intra- and inter-generational justice are not adequately incorporated-almost as if innovators were to be "protected" from engaging in reflection on their wider impact and inquiring into their underlying values and worldviews (see also Schlaile et al., 2021 on a related note). Indeed, normativity and ethical reflections are often considered to inhibit innovation and to curb economic development (see, for example, Read \& O'Riordan, 2017; Thierer, 2016).

This techno-economic bias tends to motivate the formulation of policy programs that foster innovation towards relatively segregated solution strategies that neglect long-term desirability and instead concentrate on quick remedies (see also Pyka et al., 2021). One example of a currently popular solution strategy which is at risk of disregarding the complexity of problems and outcomes is the bio-based economy or bioeconomy. Globally, many political initiatives promote the transformation towards a bioeconomy (Bioökonomierat, 2018) with the aim of overcoming our dependence on limited fossil resources and combating climate change (see also Pyka, 2017). The bioeconomy is also expected to contribute significantly to socioeconomic wellbeing. For example, it holds the promise of safeguarding food supply, potentially providing a "buffer role" for employment in times of crisis (Ronzon \& M'Barek, 2018), and offering a means for the transformation to an innovative, future-oriented and competitive economy (Ronzon et al., 2020). As such, the notion of the bioeconomy claims to provide to a set of techno-economic quick fixes as win-win solutions for all stakeholders - an endeavor that has been argued to be physically impossible (Giampietro, 2019).

Despite its indisputable potential as part of a socioeconomic transformation towards sustainability, however, the bioeconomy is a good example of a political program whose successful implementation inevitably hinges on its normative focus. It is this philosophical aspect of the bioeconomy in particular that remains underdeveloped in current research, with only a few exceptions (Veraart \& Blok, 2021, 2022). At the same time, the relatively short history of the bioeconomy as a political program-since its first introduction in EU policies in 2005 (oekom e.V., 2020) already provides ample examples of aberrations that can at least be partly attributed to a lack of normativity and providence (see, for example, Albrecht et al., 2012; Bruckner et al., 2019; Escobar et al., 2018; Tittor, 2020). It is becoming more and more obvious that the current innovation logic with its reliance on market forces and purely technological solutions does not provide sufficient orientation towards future developments that avoid ecological deterioration and societal disruption (Blok, 
2020). In this connection, it becomes evident that the bioeconomy constitutes what Gallie (1956) called an essentially contested concept - as has already been argued in a similar way for the circular economy (Korhonen et al., 2018). According to Gallie (1956), due to people's diverging value frames, a concept may invoke divergent interpretations while being commonly used even by groups with different opinions and interests. Although it might be disputed that all of Gallie's (1956) conditions for being considered an essentially contested concept hold, the bioeconomy is clearly "appraisive" as it signifies a valued achievement, which is of a complex nature that can be explained from various angles. And most bioeconomy researchers can also be assumed to be aware that theirs is not the only valid or correct use of the concept. For better or worse, it is the nature of these very perceptions and values guiding bioeconomy research and innovation that will be pivotal in determining whether the bioeconomy is able to safeguard the existence of our species or further worsen our prospects on this planet.

A transformation towards a bioeconomy raises ethical issues of intergenerational and intra-generational equity, for instance (Murray et al., 2017). Questions of how to meet global demands in terms of food, health, material, and energy must be tackled synchronously with issues of human rights, social inclusion, fitness for future, and the question of "how do we want to live". So far, the assumed characteristics of the biosphere and the economic sphere and their interdependencies in a bio-based future remain unexpressed (Veraart \& Blok, 2021; Zwier et al., 2015). In times of interconnected social and ecological challenges, the complexity of the problems humanity is facing can become overwhelming. This complexity must be encountered by a systemic take on solutions capable of addressing the multiplicity of causes and effects and mainstreamed by their explicit and deliberative normative orientation.

As a consequence, isolated research into technical feasibility on the one hand and ethical normativity on the other hand will undoubtedly remain futile without a profound understanding of the complex socio-economic processes that connect the two realms. Interdisciplinary reflection is needed that brings together philosophers, economists and other social scientists, sustainability researchers, cultural evolutionists, and complexity scientists to advance the debate. This was the intention of the organizers of the interdisciplinary workshop "The Normative Dimension of Transformations towards a Sustainable Bioeconomy-Expanding the Economic Perspective" at the University of Hohenheim on September 13-14, 2019, which was funded by the Baden-Württemberg Ministry of Science, Research and the Arts, the German Research Foundation, and Universitätsbund Hohenheim e.V. Our workshop was attended by 43 researchers from ten different countries and representing a range of disciplines including the natural sciences, agriculture, economics, sociology, and ethics. Most of the contributions to this collection were first presented and discussed at this workshop. By presenting this topical collection, we therefore aim to present a snapshot of this important debate while at the same time inviting other researchers to tap into and join in these discussions on normative issues in the context of transformations towards not just any bioeconomy but a sustainable one.

In an innovative approach, Hugo de Vries and others capture the multi-dimensional potential development space of a sustainable bioeconomy (de Vries et al., 2021). With the help of the proposed 'Cylinder' framework, the authors present a 
new model for analyzing and comparing different bioeconomy systems by drawing on and combining different building blocks from doughnut economics to game theory. The cylinder model serves as a useful image for evolving bioeconomy systems that keep within normative borders while using the space between order and chaos to develop resilient system structures.

Delving more deeply into existing bioeconomy systems, Jonathan Friedrich and his colleagues analyze various bioeconomic innovations to explore their actual contribution to sustainability objectives (Friedrich et al., 2021). They develop an analytical framework that enables them to judge whether the four innovations under observation contribute to the achievement of the central categories that define a socio-ecological transformation. Their results show that the analyzed manure-based agricultural innovation cases mainly follow a rather conventional innovation paradigm without contesting the values, imaginaries, and beliefs of incumbent market actors. Consequently, the capacity of these innovations in terms of significantly contributing to socio-ecological transformations can be expected to be rather limited. One important conclusion to be drawn from their research is that in order to better align bioeconomy innovation with the aims of socio-ecological transformations, research must ensure the involvement of stakeholders in the development of innovation via transdisciplinary research approaches.

This is exactly the issue that Anne-Charlotte Hoes and her co-authors address. Based on reflections on a series of stakeholder workshops organized as part of the European H2020 Collective Action project BIOVOICES, they elaborate on the question of what value stakeholder involvement brings to the transition to bioeconomy (Hoes et al., 2021). The most important cognizance from their research is that, in addition to creating legitimacy and drawing on co-creative power, the involvement of those that are affected by bioeconomy innovations can-if handled with careprovide insight into the dependencies between players in the market that hamper the transition. The authors further take it upon themselves to outline the requirements that successful stakeholder involvement should meet when it is to support transitioning processes towards bioeconomy. Their clear advice here is to invite a good mix of persons concerned to the table and make sure that current market actors are wellrepresented so as to have them on board when the transition gains momentum.

While the first three articles focus more on the systems and producers of bioeconomy, the other two teams of researchers aim to shed light on the roles and activities of consumers within the bioeconomy and within the scientific literature on bioeconomy.

Ulrich Wilke's team sheds light on the perceived role of consumers in the bioeconomy transition as reflected in the academic literature (Wilke et al., 2021). The authors build on the argument that the bioeconomy transition must involve consumers as potentially active agents. This means that consumers are not merely passive participants within the structural transition towards a sustainable bioeconomy but share responsibility with other actors in the system. The article scans the current scientific bioeconomy literature for contributions regarding the consumers' scope of action and concludes that the consumer is treated as a mostly passive entity within this literature. Against the backdrop of their theoretical considerations, the authors call upon the academic bioeconomy community to address the various roles and 
responsibilities of consumers more explicitly in future empirical and conceptual research.

Siegmar Otto and colleagues explore what role consumers' sustainability motivation plays in terms of the successful introduction of a circular sustainable bioeconomy and what drivers of their motivation are of particular importance (Otto et al., 2021). They conclude that a bioeconomy cannot fulfil the requirements of a sustainable system as long as consumers' behavior is not addressed. Their decisions must be considered a decisive pull factor for a sustainable bioeconomy. These insights imply that along with the facilitation of the technical development of the bioeconomy, policies must motivate consumers to support the bioeconomy by lowering the behavioral costs of bio-consumption and strengthening society's overall sustainability motivation.

While the five articles published in our collection are highly diverse in terms of their intellectual background and approach, they have one important finding in common: they highlight the need for more research into the normative dimension of transformations towards a sustainable bioeconomy and indeed they pave the way for such an approach.

Funding Open Access funding enabled and organized by Projekt DEAL.

\section{Declarations}

Conflict of interest The authors declared that there is no conflict of interest.

Open Access This article is licensed under a Creative Commons Attribution 4.0 International License, which permits use, sharing, adaptation, distribution and reproduction in any medium or format, as long as you give appropriate credit to the original author(s) and the source, provide a link to the Creative Commons licence, and indicate if changes were made. The images or other third party material in this article are included in the article's Creative Commons licence, unless indicated otherwise in a credit line to the material. If material is not included in the article's Creative Commons licence and your intended use is not permitted by statutory regulation or exceeds the permitted use, you will need to obtain permission directly from the copyright holder. To view a copy of this licence, visit http://creativecommons.org/licen ses/by/4.0/.

\section{References}

Albrecht, S., Gottschick, M., Schorling, M., \& Stirn, S. (2012). Bioökonomie am Scheideweg Industrialisierung von Biomasse oder nachhaltige Produktion? GAIA-Ecological Perspectives for Science and Society, 21(1), 33-37.

Bioökonomierat. (2018). Bioeconomy Policy (Part III): Update report of national strategies around the world. A report from the German Bioeconomy Council. https://biooekonomierat.de/filea dmin/Publikationen/berichte/GBS_2018_Bioeconomy-Strategies-around-the_World_Part-III.pdf

Blok, V. (2020). What is innovation? laying the ground for a philosophy of innovation. Techné Res Phil Technol, 25(1), 1-15. https://doi.org/10.5840/techne2020109129

Blok, V. (2022). The normative and social dimensions of the transition toward a responsible circular biobased economy. In S. Lamalle \& P. Stoett (Eds.), Representations and Rights of the Environment. Cambridge University Press (forthcoming). 
Bruckner, M., Häyhä, T., Giljum, S., Maus, V., Fischer, G., Tramberend, S., \& Börner, J. (2019). Quantifying the global cropland footprint of the European Union's non-food bioeconomy. Environmental Research Letters, 14(4), 45011. https://doi.org/10.1088/1748-9326/ab07f5

Bryden, J., \& Gezelius, S. S. (2017). Innovation as if people mattered: The ethics of innovation for sustainable development. Innovation and Development, 7(1), 101-118. https://doi.org/10.1080/ 2157930X.2017.1281208

de Vries, H., Donner, M., \& Axelos, M. (2021). A new conceptual 'cylinder' framework for sustainable bioeconomy systems and their actors. Journal of Agricultural and Environmental Ethics, 34(2), 11. https://doi.org/10.1007/s10806-021-09850-7

Escobar, N., Haddad, S., Börner, J., \& Britz, W. (2018). Land use mediated GHG emissions and spillovers from increased consumption of bioplastics. Environmental Research Letters, 13(12), 125005. https://doi.org/10.1088/1748-9326/aaeafb

Friedrich, J., Bunker, I., Uthes, S., \& Zscheischler, J. (2021). The potential of bioeconomic innovations to contribute to a Social-ecological transformation: A case study in the livestock system. Journal of Agricultural and Environmental Ethics, 34(4). https://doi.org/10.1007/ s10806-021-09866-Z

Gallie, W. B. (1956). Essentially contested concepts. Proceedings of the Aristotelian Society, 56(1), 167-198. https://doi.org/10.1093/aristotelian/56.1.167

Giampietro, M. (2019). On the circular bioeconomy and decoupling: Implications for sustainable growth. Ecological Economics, 162, 143-156. https://doi.org/10.1016/j.ecolecon.2019.05.001

Hoes, A.-C., van der Burg, S., \& Overbeek, G. (2021). Transitioning responsibly toward a circular bioeconomy: Using stakeholder workshops to reveal market dependencies. Journal of Agricultural and Environmental Ethics. https://doi.org/10.1007/s10806-021-09862-3

Korhonen, J., Nuur, C., Feldmann, A., \& Birkie, S. E. (2018). Circular economy as an essentially contested concept. Journal of Cleaner Production, 175, 544-552. https://doi.org/10.1016/j.jclep ro.2017.12.111

Murray, A., Skene, K., \& Haynes, K. (2017). The circular economy: An interdisciplinary exploration of the concept and application in a global context. Journal of Business Ethics, 140(3), 369-380. https://doi.org/10.1007/s10551-015-2693-2

oekom E.V. (2020). Bioökonomie - Weltformel oder Brandbeschleuniger. München.

Otto, S., Hildebrandt, J., Will, M., Henn, L., \& Beer, K. (2021). Tying up loose ends: Integrating consumers' psychology into a broad interdisciplinary perspective on a circular sustainable bioeconomy. Journal of Agricultural and Environmental Ethics, 34, Article 8. https://doi.org/10.1007/ s10806-021-09851-6

Pyka, A. (2017). Dedicated innovation systems to support the transformation towards sustainability: Creating income opportunities and employment in the knowledge-based digital bioeconomy. Journal of Open Innovation: Technology, Market, and Complexity, 3(1), 385. https://doi.org/10. 1186/s40852-017-0079-7

Pyka, A., Ari, E., Alva-Ferrari, A., \& Urmetzer, S. (2021). The bioeconomy transition process: Sailing through storms and doldrums in unknown waters. Journal of Innovation Economics \&amp; Management, Prépublication. https://doi.org/10.3917/jie.pr1.0110

Read, R., \& O'Riordan, T. (2017). The precautionary principle under fire. Environment: Science and Policy for Sustainable Development, 59(5), 4-15. https://doi.org/10.1080/00139157.2017.13500 05

Ronzon, T., \& M'Barek, R. (2018). Socioeconomic indicators to monitor the EU's bioeconomy in transition. Sustainability, 10(6), 1745. https://doi.org/10.3390/su10061745

Ronzon, T., Piotrowski, S., Tamosiunas, S., Dammer, L., Carus, M., \& M'barek, R. (2020). Developments of economic growth and employment in bioeconomy sectors across the EU. Sustainability, 12(11). https://doi.org/10.3390/su12114507

Schlaile, M. P., Kask, J., Brewer, J., Bogner, K., Urmetzer, S., \& de Witt, A. (2021). Proposing a cultural evolutionary perspective for dedicated innovation systems: Bioeconomy transitions and beyond. Journal of Innovation Economics \&amp; Management, Prépublication. https://doi.org/ 10.3917/jie.pr 1.0108

Schlaile, M. P., Urmetzer, S., Blok, V., Andersen, A., Timmermans, J., Mueller, M., Fagerberg, J., \& Pyka, A. (2017). Innovation systems for transformations towards sustainability? Taking the normative dimension seriously. Sustainability, 9(12), 2253. https://doi.org/10.3390/su9122253 
Thierer, A. D. (2016). Permissionless innovation: The continuing case for comprehensive technological freedom (Revised and expanded edition). Mercatus Center George Mason University. https:// www.mercatus.org/system/files/Thierer-Permissionless-revised.pdf

Tittor, A. (2020). Unschöne Nebenwirkungen. In oekom e.V. (Ed.), Bioökonomie - Weltformel oder Brandbeschleuniger (pp. 71-76). München

Veraart, R., \& Blok, V. (2021). Towards a Philophy of a bio-based economy: A levinassian perspective on the relations between economic and ecological systems. Environmental Values, 30(2), 169-192. https://doi.org/10.3197/096327120X15916910310626

Veraart, R., \& Blok, V. (2022). Efficiency versus enjoyment: Incorporating the human condition in the transition to the bio-based economy. Journal of Agricultural and Environmental Ethics(forthcoming).

Wilke, U., Schlaile, M. P., Urmetzer, S., Mueller, M., Bogner, K., \& Pyka, A. (2021). Time to say 'Good Buy' to the passive consumer? A conceptual review of the consumer in the bioeconomy. Journal of Agricultural and Environmental Ethics, 34(4). https://doi.org/10.1007/ s10806-021-09861-4

Zwier, J., Blok, V., Lemmens, P., \& Geerts, R.-J. (2015). The Ideal of a zero-waste humanity: Philosophical reflections on the demand for a bio-based economy. Journal of Agricultural and Environmental Ethics, 28(2), 353-374. https://doi.org/10.1007/s10806-015-9538-y

Publisher's Note Springer Nature remains neutral with regard to jurisdictional claims in published maps and institutional affiliations. 